\title{
THE MOMENT OF DEATH: LAW, SOCIETY AND SCIENCE
}

\section{Introduction}

To determine the moment of death is very important for various purposes in medico-legal practice. The moment of death may not only assist and be regarded as valuable evidentiary material in criminal investigations but it is also important in the context of organ transplantation, questions regarding euthanasia, insurance claims, the termination of a marriage or business partnership as well as in the legal domain of succession. A diagnosis of death is furthermore important and necessary for society to commence with religious and/or traditional rituals, burials etcetera (Farrell and Levin "Brain Death in the Pediatric Patient: Historical, Sociological, Medical, Religious, Cultural, Legal and Ethical Considerations" Dec 21(12) 1993 Crit Care Med $1951 \mathrm{ff})$.

In order to determine the exact moment of death, however, is not an easy task, least of all a very simple and straightforward undertaking as Prof Christiaan Barnard suggested by asserting that a person is dead when the doctor says that the person is dead! (Barnard Good Life, Good Death: A Doctor's Case for Euthanasia and Suicide (1980) 11.) To determine the exact moment of death, a definition of death is required as well as a standard to diagnose death - diagnostic criteria (Joffe "The Neurological Determination of Death: What Does it Really Mean?" 2007 23(2) Issues in Law \& Medicine 120). This note will show that what initially may be regarded as general medical and legal requirements as well as basic semantics when referring to a definition of death, a concept of death and the criteria for the purposes of diagnosing death, is actually a very complicated, multifaceted and unsettled area of debate.

The focus of this note will be on the moment of death in the broader context of medico-legal practice and with specific reference to the amendments made by the National Health Act 61 of 2003 in this regard. Owing to the vast scope of the topic, the note will highlight the main debates regarding the moment of death, the definition for death and criteria for determining death. The basic principles and comments on recent developments in this particular area of medical law will also be discussed.

\section{Background}

The concept of death - which refers to an individual or group's perception of death - when it occurs and the consequences following death have always been an uncertain and controversial topic. Medical practitioners from the early Greek civilizations believed that life starts with the very first heartbeat 
and that the heart is also the very last organ to die in the death process. Great importance was later also placed on respiration and the last breath as a true indicator of death in Hebrew and Christian literature. Maimonides from the $12^{\text {th }}$ century believed that the head and the loss thereof was the centre of life (Farrell and Levin Dec 21(12) 1993 Crit Care Med 1951-1965). Likewise, the legal and medical definition of death and the process and criteria for diagnosing the exact moment of death is still an inconclusive question today; constantly changing and developing with time and technological advances.

\section{Somatic death: The traditional death criterion}

The exact moment of death can actually be regarded as a legal fiction since death refers to a biological process of irreversible loss of cellular and tissue functions as well as metabolic activities (Dada and McQuoid-Mason MedicoLegal Practice (2001) 347; and compare with Thomas $v$ Anderson 215 P 2d 478 (1950) 371 , where the court stated that death is not a continuing event and is an event that takes place at a precise time and moment). Thus, biologically, no exact moment of death can be pinpointed since cells and tissue die at different intervals. The stage of somatic death, which can be characterised by cardiopulmonary failure determined by permanent cessation of spontaneous respiration, heartbeat as well as circulation, may be regarded as the traditional and generally accepted moment of death important for medico-legal practice since the Enlightenment. About four to five minutes after spontaneous respiration and circulation have ceased, irreversible damage to the brain can be observed and the consequent cessation of all functions of the central nervous system then also indicate brain death in addition to somatic death. This traditionally accepted criteria of death was, however, by the middle $20^{\text {th }}$ century no longer adequate due to the great advances in medical technology (Dada and McQuoid-Mason 347; Carstens and Pearmain Foundational Principles of South African Medical Law (2007) 204; Thomas v Anderson supra; Smith v Smith 317 Sw 2d 275 (1958); S v Williams 19864 SA 1188 (A); and Van Rooyen Die Moment van Dood (1992) 14 and 41). Developments in medical science and technological advances such as assisted artificial respiration methods in 1740 , anaesthesia by means of inhalation in 1846 and the stetoscope by Rene Laennec in 1819, challenged these early perceptions of death, dying and the moment of death (Van Rooyen 12-13). Today the increasingly sophisticated scientific methods of sustaining life artificially also blur the traditional definition and belief regarding death. The life-prolonging possibilities and ensuing consequences of such life-support systems on relatives, medical aids and health-care providers certainly also necessitated that the generally accepted definition of death and determination of the moment of death be revisited.

Until very recently, with the enactment of the National Health Act 61 of 2003 which defines the crucial moment of death as brain death (s 1), no official legal definition existed in South African law to determine the exact moment of death. In practice the traditional criterion of somatic death was used to determine the moment of death (compare with the situation in the 
United States of America where a legal definition of death was agreed upon in 1968 with the ad hoc committee report of the Harvard Medical School and the Uniform Declaration of Death Act of 1981; and Carson "Redefining Death" 1987 New England Journal of Medicine 316: 17 1101-1102). Both medical practitioners as well as the courts concurred that the cessation of spontaneous respiration, circulation and heartbeat was sufficient to conclude that somatic death had occurred and that the consequent legal implications of this formal recognition of death were to follow (Barnard 1967 SA Mediese Tydskrif 1271; S v Williams supra; and Clarke v Hurst NO 19924 SA 630 (D)).

However, in the case of $S v$ Williams (supra 1194) the medical examiner, who had switched off the deceased's ventilator, stated that the moment of brainstem death is the critical moment of death and that the ventilator was only switched off once it was determined that the deceased had no brainstem function. Although Rabie CJ did not address the question whether brain death, brainstem death or somatic death should be regarded as the moment of death in South African law, he did emphasise that the traditional legal convictions of the community, religious beliefs as well as moral convictions should be taken into consideration by the law when deciding on a precise and appropriate legal definition for the moment of death. The popular understanding of the moment of death might very well differ from the definition suggested by medical science. In this case the cessation of spontaneous respiration, circulation and heartbeat was regarded as the mechanism indicating somatic death and consequently the moment of death. But, this case also introduced the very first signs of debate and disparity in the South African legal and medical realm on when the exact moment of death was and how it should be determined.

\section{$4 \quad$ Neo-cortical death}

In the case of Clarke $v$ Hurst (supra) yet another approach and understanding of the concept of death was introduced. Here the court was of the opinion that:

"The maintenance of life in the form of certain biological functions such as the heartbeat, respiration, digestion and blood circulation but unaccompanied by any cortical and cerebral functioning of the brain, cannot be equated with living in the human or animal context" (supra 658).

In this particular case the deceased was not brain dead but was in a permanent, irreversible vegetative state with no hope of recovery. The deceased had no cognition of his surroundings or consciousness and was dependent on full-time care as well as a naso-gastric tube for feeding. This state of existence or rather non-existence can be defined by the term neocortical death. This concept of death which was accepted in this particular case refers to an individual, who cannot be defined as brain dead and who still demonstrates the vital biological functions of the body, including a heartbeat, circulation and spontaneous respiration but has suffered irreversible damage to the cortex of the brain (Carstens and Pearmain 
Foundational Principles of South African Medical Law (2007) 203-207). It is in cases like these that questions regarding euthanasia, life-support systems and life-sustaining measures and whether withdrawal of such treatment is natural/usual or unnatural/unusual come to the fore.

The judgment in the case of Clarke $v$ Hurst (supra) and the acceptance of the concept neo-cortical death in the South African law certainly allows for very interesting discussions and interpretations in the field of medical law, especially in the context of euthanasia. This case was also another step away from the traditional death criterion in South African law towards the more internationally popular (by that stage) concept of brain death as a criterion for determining the moment of death. Neo-cortical death refers to the irreversible loss of consciousness and cognitive functions. Although the court in this case did not suggest a new general definition for the moment of death, the acknowledgement of the loss of higher brain functions like personal identity, personality, consciousness and cognitive actions to aid a decision to terminate artificial feeding certainly indicated a progression from the traditional criterion of somatic death to a new understanding of the moment of death. It is important to note, however, that in this case the concept of neo-cortical death was accepted to validate the termination of artificial feeding in order for death to realise. The acceptance of the concept neo-cortical death in this case did not confer the status of being legally dead on the patient. The acceptance of the concept rather resulted in death.

\section{$5 \quad$ Brain death}

Whole brain death refers to the irreversible cessation of all functions of the entire brain, including the brainstem, while brainstem death refers to the irreversible cessation of the functions of the brainstem, which refers to a person's vital signs. The concept of brain death/cerebral death was first introduced in France, 1959 to describe a state referred to as coma dèpassè, literally meaning the state beyond coma. Patients in this state show no brain activity or reflexes and have lost the capacity to breath spontaneously, there is no hope of recovery (Schoen "Conflict in the Parameters Defining Life and Death in Missouri Statutes" 1990 XVI(4) American Journal of Law \& Medicine 567). A further impetus and development towards the recognition of brain death as the critical moment of death was a publication by an ad hoc committee of the Harvard Medical School in 1968 focusing on the elements and criteria of brain death. This committee regarded brain death as a state of irreversible coma, the patient does not react to any external stimulation, has no independent respiratory function and has no reflexes. The findings of this committee were accepted by the President's Commission for the Study of Ethical Problems in Medicine and Biomedical and Behavioral Research which led to the general recognition of brain death as the critical moment of death in the medical realm and the formulation of the Uniform Determination of Death Act of 1981 in the United States of America (Sperling "Maternal Brain Death" 200430 American Journal of Law \& Medicine 479). Kansas was the first state in the USA to incorporate a statutory definition of brain death in 1967, while Finland was the first country in which brain death was 
legally accepted, in 1975. Brain death was also accepted as the critical moment of death in England in 1979 (Van Rooyen 43-47; Medical Royal Colleges and Faculties of the United Kingdom Cadaveric Organs for Transplantation (1983) 36; Airedale NHS Trust v Bland (1993) 1 AC 789 (HL); Capron "Brain Death - Well Settled yet Unresolved" 2001 344(16) New England Journal of Medicine 1244-1246). Although most jurisdictions followed suit and accepted brain death as the critical moment of death, there still is no global consensus in the diagnostic criteria of brain death, in other words, the standards that should apply to determine whether an individual is brain dead (Karakatsanis and Tsanakas "A Critique on the Concept of Brain Death" 2002 18(2) Issues in Law and Medicine 128; Levin and Whyte "Brain Death Sans Frontieres" 1988 318(13) New England Journal of Medicine 852-854; Ten Velden and Van Huffelen "Brain Death Criteria: Guidelines by the Public Health Council" 1997 141(2) Ned Tijdschr Geneeskd 77-79; Kaste and Palo "Criteria of Brain Death and Removal of Cadaveric Organs" 1981 13(4-5) Ann Clin Res 313-317; and Haupt and Rudolf "European Brain Death Codes: A Comparison of National Guidelines" $1999246 \mathrm{~J}$ Neurol $432-$ 437). A clinical neurologic examination and the apnea test are usually sufficient to conclude a diagnosis of brain death. (Farrell and Levin Dec 21(12) 1993 Crit Care Med 1951-1965; and Wijdicks "Current Concepts: The Diagnosis of Brain Death" 2001 344(16) New England Journal of Medicine 1215-1221).

Many argue that the recognition of brain death as the critical moment of death, which is largely based on and a direct consequence of the publication by the ad hoc committee of the Harvard Medical School in 1968, is actually a misconception. It is said that the ad hoc committee in fact advocated for the recognition of a state of irreversible coma and a new concept of death and not a new definition and standard set of criteria for determining the moment of death. Another argument against the use of brain death as the definition and criterion of death arises in situations where patients show no brain activity for an extensive period of time and may now, according to the new definition on the moment of death, be declared officially dead. This is regardless of the fact that medical science has observed cases where patients did not show any brain activity for a period and afterwards fully recovered. This was especially evident in patients who had consumed large quantities of drugs which depress the central nervous system, cases of hypothermia and locked-in syndrome (Wijdicks 2001 344(16) New England Journal of Medicine 1215-1221). It has also been noted in some instances that children with a diagnosis of brain death continue to grow and pregnant women who were declared brain dead have delivered healthy babies up to four months after the brain death diagnosis (Finucane "Brain Death" 2002 346(10) New England Journal of Medicine 786; Wijdicks 2001 344(16) New England Journal of Medicine 1215-1221; Van Rooyen 44-45 and 75-76; Karakatsanis and Tsanakas 2002 18(2) Issues in Law and Medicine 127141).

The main arguments for and against the concept of brain death can be classified into two groups: The biological arguments include all arguments dealing with the biological/medical and physical proof that brain death is the 
ultimate and true moment of death. Moral arguments for brain death include arguments pertaining to what is regarded as morally acceptable in situations of irreversible coma. Some of these arguments will be discussed in the following section of this note (Green and Wikler "Brain Death and Personal Identity" in Battin, Francis and Landesman Death, Dying and the End of Life Vol I (2007) 47-75). Despite such arguments, most countries now recognize whole brain death as the definite moment of death.

\section{Brain death as the decisive moment of death in South Africa}

The legislator in South Africa has now also accepted brain death as the moment of death in South Africa according to section 1 of the National Health Act 61 of 2003. The greatest advantage of the definition introduced by the National Health Act 61 of 2003 is probably in the context of organ transplantation. By defining the moment of death as brain death it will now be possible to remove organs from the deceased's body before respiration and circulation or heartbeat has ceased, which will ensure that more organs are viable for transplantation since the depletion of oxygen and circulation usually leads to cellular death in most organs which in turn results in the organs not being suitable for transplantation (Arnold and Youngner "The Dead Donor Rule: Should we Stretch it, Bend it, or Abandon it?" in Battin, Francis and Landesman Death, Dying and the End of Life Vol I (2007) 85100; and Youngner "Some Must Die" in Battin, Francis and Landesman Death, Dying and the End of Life Vol I (2007) 101-120).

It remains unclear though why the legislator incorporated this definition of death in the National Health Act, what the criteria for determining brain death is and what the practical implications of this unilateral decision (the decision was not debated in the public sphere, traditional legal convictions of the community, religious beliefs as well as moral convictions of the South African community was also not considered) will be. The note will now continue to consider some religious, cultural and ethical considerations relevant to the definition of brain death as the moment of death in the South African context.

\section{Death: religious, cultural and ethical considerations}

Once a person is dead many traditional, religious as well as contemporary rituals and practices are called upon and performed. Family and friends engage in religious acts even though they are not religious people. (Carnevale "The Palliation of Dying: A Heideggerian Analysis of the 'Technologization' of Death" April 2005 5(1) Indo-Pacific Journal of Phenomenology 1-12) The reaction to death is largely based on the individual's or group's concept of death. Since South Africa is a multi-cultural and religious nation, possible outrage against this new definition of death may come from various religious and cultural groups in South Africa. 
Particular religious groups such as traditional Catholics, fundamentalist Christians, conservative Muslims or orthodox Jews might object against brain death as the new definition of the moment of death. Van Rooyen, however, is of the opinion that most religious groups and communities would find the brain death concept acceptable. Most Islamic countries now approve of the brain death concept and most progressive Jews also accept brain death as the final moment of death (Shaheen, Al-Jondeby, Kurpad and AlKhader "Social and Cultural Issues in Organ Transplantation in Islamic Countries" 2004 9(2) Ann Transplant 11-3; Michael "Discontinuation of Ventilation after Brainstem Death. Jews Accept Brainstem Death" 20 Nov 1999 319(7221) BMJ 1357). An example of where public opinion was in fact considered in the legal definition of death is in New Jersey where it is accepted that a person can only be declared brain dead if that person's religious beliefs and cultural traditions allow for such a diagnosis and the legal implications of such a diagnosis (Finucane 2002 New England Journal of Medicine 786; and Capron 2001 New England Journal of Medicine 1245). A similar regulation was implemented in 1987 in New York (Capron 2001 New England Journal of Medicine 1245; and Declaration of Death L1991 Ch 90, NJSA 26:6A-5).

The traditional African perception of death has also been influenced to some extent by social change and Western medicine. Complex and long rituals and ceremonies, however, still mark a death in a family and/or community. In a Zulu tribe the oldest family members will stay close to the dying individual and will listen closely for the cessation of the heartbeat, which indicates the moment of death (Jali The African Perception of Death, with Special Reference to the Zulu: A Critical Analysis (2000) MPhil University of Stellenbosch). Knowledge and awareness of the Western medical system can play a more important role in how traditional Africans perceive the moment of death rather than culture and religion.

An ethical argument to consider is whether a diagnosis of brain death confers the status of death on the individual in question or whether a diagnosis of brain death merely provides the medical practitioner the opportunity to declare the individual as dead. Does a medical practitioner have a duty to declare the individual dead as soon as brain death is confirmed? A possible indication of what the general public's perception on brain death might be is that many lay people classify legally living persons in irreversible coma or a persistent vegetative state (PVS) as dead even though these individuals medically only have an injury to the cerebral hemispheres of the brain and not the entire brain (Veatch "Abandon the Dead Donor Rule or Change the Definition of Death?" Sept 2004 14(3) Kennedy Inst Ethics J 261-276). The general public also tend to be more outspoken and involved in debates and situations on when life begins rather than when it ends (Youngner, Arnold and Shapiro The Definition of Death: Contemporary Controversies (1999) 1-368). 


\section{$8 \quad$ Conclusion}

Although it is evident that a legal definition for the critical moment of death is necessary to provide certainty and guidance, especially in light of the rapid and numerous advances in medical technology, how medical practitioners and the courts will interpret this new legal definition and whether the definition will change the way in which practitioners traditionally determined the exact moment of death, for now, remains unclear.

This note also showed how easily the concept of death, the legal definition of death and the medical diagnostic criteria to determine the exact moment of death are confused. What may appear to be a question of semantics is actually a complex issue, especially when considering whether a medical practitioner has a duty to confer the status of death on a brain dead patient or whether the status of brain death merely provides the medical practitioner with the opportunity to do so.

In the same way many communities, cultures, religious groups and other factions may have their own ideas and beliefs on exactly when a person is regarded as dead and when that moment of death actually occurs irrespective of what medical science suggests (Cranston et al "The Diagnosis of Brain Death" 2001 345(8) New England Journal of Medicine 616-623; Wijdicks 2001 344(16) New England Journal of Medicine 12151221; and http://www.catholicnews.com/data/stories/cns/0605285.htm accessed on 27 July 2007). It is therefore very unfortunate that such a legal definition for death was introduced in the National Health Act 61 of 2003 without any known public discussion on the topic, a discussion focusing specifically on the traditional legal convictions of the general community, religious beliefs as well as moral convictions like Rabie CJ suggested in the case of $S \vee$ Williams discussed above. The moment of death cannot be regarded as an objective technical concept but is rather a subjective, valueladen belief (Van Rooyen 15). Indeed, it can be viewed as a question of social policy to be decided by the community (Van Rooyen 55). That said, however, it is doubtful that the general public in South Africa will object to this new legal definition of death. It can be assumed that most people regard cases of neo-cortical death as true death already. Should a particular patient or relative object to the concept of brain death it is advisable that hospitals and practitioners provide for a reasonable accommodation of alternative viewpoints, like the states of New Jersey and New York in the United States of America have.

Ultimately I have to agree with Dworkin (1973):

"The effort devoted to defining death is wasted at best, counterproductive at worst ... The most basic question [is]: What difference does it make whether somebody is dead? The question places the issue of death into the only posture in which it can be of relevance to the law - the posture of context or consequences."

Andra le Roux-Kemp University of Stellenbosch 